9. Ухвала Волинського окружного адміністративного суду від 28 серпня 2015 р. по справі № 803/2328/15. [Електронний ресурс]. Режим доступу: http://reyestr.court.gov.ua/Review/49643852.

10. Ухвала Київського окружного адміністративного суду від 26 вересня 2012 р. по справі № 2a-7460/12/2670. [Електронний ресурс]. Режим доступу: http://reyestr.court.gov.ua/ Review/26282112.

11. Цивільний процесуальний кодекс України : Кодекс України, Кодекс, Закон від 18.03.2004 № 1618-IV/Верховна рада України. Відомості Верховної Ради України (ВВР). 2004. № 40-41, 42, C. 492.

УДК 342.9

DOI https://doi.org/10.32844/2618-1258.2019.5-2.38

ЩУПАКІВСЬКИЙ Р.В.

\title{
ПРАВОВІДНОСИНИ У СФЕРІ ТЕЛЕКОМУНІКАЦЙ: ЮРИДИЧНИЙ АНАЛІЗ, КЛАСИФІКАЦІЯ
}

\begin{abstract}
У статті представлено авторський погляд на категорію телекомунікаційних правовідносин як предмет правового регулювання окремої новоствореної галузі національного права - телекомунікаційного права. Визначено критерії відмежування вказаних правовідносин від адміністративних, цивільних та інших. Надано класифікацію телекомунікаційних правовідносин з різними критеріями як основного предмета правового регулювання телекомунікаційного права. Визначено, що суб'єкт телекомунікаційних правовідносин - це особа (держава, посадова особа, громадянин, юридична особа, служба зв'язку), яка здійснює в телекомунікаційній сфері юридично значиму діяльність на постійній або тимчасовій основі (регулювання діяльності в телекомунікаційній сфері, експлуатацію телекомунікаційних об'єктів або ресурсів, отримує послуги в телекомунікаційній сфері), або виконує окремі функції з телекомунікаційною інфраструктурою. Доведено, що найбільш значимий для користувача в телекомунікаційній сфері юридичний факт - надання оператором зв'язку доступу для абонента. Наголошено, що розгляд основних понять та категорій будь-якої галузі права досить кропіткий та потребує уважного дослідження, до якого входить процес вивчення значної кількості проблемних питань як-то предмет правового регулювання, його метод, принципи окремої галузі права, правові відносини, які виникають у відповідній сфері суспільного життя, суб'єкт, об'єкт, зміст цих правовідносин тощо. Зроблено висновок, що контекст взаємозв'язку відносин у суспільстві, які складають предмет телекомунікаційного права, 3 іншими галузями права зумовлюється специфікою потреб їх учасників на рівні приватного права та окремими ознаками галузей публічного права. Однак зв'язок адміністративно-телекомунікаційного права та інших основних галузей права буде розглянуто в наступному розділі цієї наукової роботи.
\end{abstract}

Ключові слова: інформаційні ресурси, приєднана мережа, телекомунікації, зв'язок, оператор, трафік, інформачійний нейтралітет.

The article presents an author's view on the category of telecommunications legal relations as a subject of legal regulation of a separate newly created field of national law - telecommunications law. The criteria for distinguishing these legal relationships from administrative, civil and other ones are determined. Classification of telecommunication legal relations with different criteria as the main subject of legal regulation of telecommunication law is given. It is determined that telecommunications legal entity is a person (state, official, citizen, legal entity, communication service), which carries out

() ЩУПАКІВСЬКИЙ Р.В. - кандидат юридичних наук, директор департаменту безпеки (Група компаній «Терра Фуд») 
legally significant activity in telecommunication sphere on a permanent or temporary basis (regulation of activity in telecommunication sphere, operation of telecommunication services Objects or resources, receives services in telecommunication sphere), or performs separate functions with telecommunication infrastructure. It is proved that the most important legal fact for the user in telecommunication sphere is to provide operator with telecommunication access for the subscriber. It is emphasized that consideration of the basic concepts and categories of any branch of law is a very painstaking and attention-seeking type of research, which includes the process of studying a large number of problematic issues, such as the subject of legal regulation, its method, principles of a particular field of law, legal relations that arise in the relevant sphere of public life, subjects, object, content of these relationships, etc. It is found out that the specificity of the content of relations in the society that make up the subject of telecommunications law, based on the concept of its understanding through the criterion of the sub-branch of the special part of the complex branch of law (information law), is determined by the third level. It is concluded that the context of the interconnection of relations in the society constituting the subject of telecommunications law with other branches of law is determined by the specific needs of their participants at the level of private law and by some features of the branches of public law. However, the relationship between administrative and telecommunications law and other major areas of law will be covered in the next section of this paper.

Key words: information resources, connected network, telecommunications, communication, operator, traffic, informational neutrality.

Вступ. Сучасні досягнення у сфері розвитку інформаційних та комунікаційних технологій зумовлюють формування зовсім нових відносин у житті людини. Після втрати чинності Закону України «Про зв'язок» суспільні відносини в цій сфері стали регулюватися Законом України «Про телекомунікації». Деякі його аспекти віддзеркалені в законах України «Про інформацію» [1], «Про поштовий зв'язок» [2], «Про радіочастотний ресурс в Україні» [3], в указі Президента «Про Національну комісію, що здійснює державне регулювання у сфері зв'язку та інформатизації» [4], у постановах Кабінету Міністрів України «Про затвердження Правил охорони ліній зв'язку» [5], «Про затвердження Правил надання та отримання телекомунікаційних послуг» [6], у рішенні Національної комісії з питань регулювання зв'язку України «Про затвердження Правил взаємоз'єднання телекомунікаційних мереж загального користування» [7], у міжнародних договорах тощо.

Постановка завдання. Метою статті $є$ проаналізувати адміністративні правовідносини у сфері телекомунікацій. Як і будь-які інші суспільні відносини, адміністративно-правові відносини у сфері телекомунікацій включають такі елементи як суб'єкт, об'єкт та зміст даних правовідносин. Саме ці елементи і стануть предметом дослідження.

У залежності від особливостей дослідження, адміністративно-правові відносини у межах сфери телекомунікацій класифікують і за іншими ознаками. Наприклад, правовідносини можна класифікувати за їхнім об'єктом, суб'єктами, за функціональним призначенням (регулятивні чи охоронні, виходячи із правомірності чи неправомірності поведінки, за якої вони виникли), тощо.

В основі роботи покладено дослідження праць таких науковців як Волков Ю.В, Девяткин Е.Е., Дудник Р.М., Дудник Р.М., Ефанов А.В., Ссімов С.С., Клементьев А.С., Копилов В.А., Ляшенко Р.Д., Мураховська Т.С., Никифоров В.С., Остапенко Ю.І., Разуваєв Н.В., Свірчевська Ю.А., Фатьянов А.А., Хохлачев Н.А., Чаннов С.С. та інші.

Результати дослідження. Адміністративно-правові відносини в межах сфери телекомунікацій визначають через категорію суспільних відносин, які врегульовуються правовими положеннями адміністративного законодавства та ті, що виникають через правомірне функціонування телекомунікаційних мереж (споруд) і задоволення потреб споживачів телекомунікаційного характеру $[10,120]$.

Так, виділення спеціального статусу суб'єктів телекомунікаційних відносин є безпосередньою ознакою формування сфери телекомунікацій. Зважаючи на погляди науковців на теорії держави та права, суб'єктом можна визначити:

1) по-перше, особу, учасника відносин суспільства у відповідній сфері, яка має права й обов'язки; 
2) по-друге, особу, яка насправді може бути учасником суспільних відносин з огляду на юридичні норми [11].

Якщо спробувати охарактеризувати всі відносини у сфері телекомунікацій, то можна їх класифікувати та виокремити такі адміністративно-правові з них:

- відносини у сфері охорони ліній та споруд (охоронні відносини);

- відносини щодо надання й отримання послуг телекомунікаційного характеру;

- відносини в межах сфери телекомунікаційного управління [8, 119];

- дозвільні відносини у сфері телекомунікацій $[9,425]$.

У телекомунікаційній сфері суб'єкти перебувають у різних відносинах (організаційних, виробничих та інших). Головними ознаками суб'єкта в телекомунікаційній сфері буде наявність у нього законних прав та обов'язків і юридично значуща діяльність в телекомунікаційній сфері. На основі перерахованих критеріїв можемо сформулювати загальне визначення суб'єкта телекомунікаційних правовідносин в телекомунікаційній сфері. Суб'єкт телекомунікаційних правовідносин - це відокремлений суб'єкт, наділений правами, відповідно до норм права, або державною функцією з регулювання відносин у телекомунікаційній сфері. Це може бути суб'єкт, який отримав дозвіл (ліцензію) і ресурси (нумерації мереж, номінали радіочастот) для телекомунікаційної діяльності, який здійснює прийом, обробку й передачу інформації з дотриманням інформаційного нейтралітету; або такий, що отримав доступ до телекомунікаційних мереж та ресурсів задля отримання послуг із прийому, обробки й передачі інформації. Головними ознаками суб'єкта в телекомунікаційній сфері $є$ наявність у нього законних прав, обов'язків і юридично значуща діяльність в телекомунікаційній сфері [12].

Досить значущою характерною рисою учасника адміністративних правовідносин у межах сфери телекомунікацій постає його взаємозв'язок з іншими суб'єктами й об'єктами телекомунікаційних правових відносин. Відповідно до такої особливості, наведемо такі базові угрупування суб'єктів вищезазначених відносин: суб'єктів;

1) суб’єкти, які є власниками об’єктів, і такі, що здійснюють регулювання відносин інших

2) суб'єкти, які є власниками об’єктів, однак вони не здійснюють регулювання відносин;

3) суб'єкти, що не є власниками об’єктів, а також ті, що не здійснюють регулювання відносин.

Для більш детального та глибокого аналізу суб’єктів правовідносин у межах телекомунікаційної сфери розглянемо поділ їх на групи. Пропонуємо їх розглянути:

1. Держава в особі різноманітних органів. До цієї категорії відносяться суб'єкти, які, відповідно до законодавства, здійснюють від імені держави регулювання діяльності в телекомунікаційній сфері, ведуть телекомунікаційну діяльність або є споживачами телекомунікаційних послуг, наприклад: держава в особі окремих органів, Україна в цілому як частина Міжнародного Союзу Електрозв'язку (МСЕ), делегація (делегати) на конференціях МСЕ, ЦВК України, дипломатичні представництва, консульські установи України, інші державні органи (Президент України, Кабінет Міністрів України, Адміністрація Державної служби спеціального зв'язку та захисту інформації України, Національна комісія, яка здійснює державне регулювання у сфері зв'язку та інформатизації, Державне госпрозрахункове підприємство «Український державний центр радіочастот» тощо).

2. Оператори та інші спеціальні суб'єкти, для яких телекомунікаційна діяльність є основним видом діяльності. Оператори зв'язку - це юридичні чи фізичні особи-підприємці, які надають послуги зв'язку на основі відповідної ліцензії (в тому числі оператор, який посідає істотне місце в мережі зв'язку загального користування; оператор універсального обслуговування - оператор зв'язку, що надає послуги зв'язку в мережі загального користування й на якого, відповідно до Закону України «Про телекомунікації», покладений обов'язок із надання універсальних послуг; організація зв'язку - це юридична особа, яка здійснює діяльність у сфері зв'язку як основний вид діяльності).

До цієї категорії відносяться: експлуатаційні організації, експлуатаційні підприємства зв'язку; визнані експлуатаційні організації, радіомовні служби, оператори зв'язку, організації зв'язку, власники ЕОМ або мереж ЕОМ, власники мереж зв'язку, інші аналогічні особи, основна діяльність яких пов'язана з експлуатацією телекомунікацій.

3. Третя група - користувачі послуг зв'язку - це особи, які користуються послугами зв'язку (в тому числі юридичні особи і громадяни, державні й муніципальні заклади, а також спеціальні суб'єкти (абоненти) - користувачі послугами зв'язку, з якими укладений договір про 
надання таких послуг), й інші споживачі зв'язку - суб'єкти, для яких споживання результатів телекомунікаційної діяльності або ресурсів є переважаючим видом діяльності в телекомунікаційній сфері, основна діяльність яких не пов'язана з телекомунікаціями.

Переходячи до питання об'єкту телекомунікаційних правовідносин, варто зазначити, що ця категорія постає однією з найважливіших елементів у складі правових відносин, вона $є$ безпосередньою основою для того, щоб віднести відносини саме до сім'ї телекомунікаційних правовідносин. Далі пропонується розглянути питання виявлення єдиної та загальної характерної риси об'єкта та класифікації самостійних об'єктів правових відносин як основного напрямку щодо вирішення зазначеної проблеми.

До об’єктів адміністративних правовідносин у сфері телекомунікацій відносяться землі телекомунікацій та земельні ділянки, надані для потреб зв'язку в постійне (безстрокове) або безоплатне термінове користування, оренду або передаються на праві обмеженого користування чужою земельною ділянкою (сервітут) фізичним особам-підприємцям та юридичним особам задля здійснення для будівництва та експлуатації споруд зв'язку, а саме розташування лінійних, станційних споруд, антен, веж, інших технічних засобів телекомунікацій $[13,10]$.

Також об'єктом є мережа зв'язку. Мережа зв'язку структурно $є$ технологічною системою, яка вміщує в собі різноманітні засоби та лінії зв'язку. Вона призначена для втілення цілей електро- чи поштового зв'язку.

До цієї ж групи можна включити також допоміжні об’єкти (технічні засоби для передачі і прийому сигналів електрозв'язку по лініях зв'язку, які підключені до абонентських ліній і які знаходяться в користуванні абонентів; споруди зв'язку; монтована ємність).

Матеріальні (блага) об'єкти, споруди та фінанси зв'язку: лінійно-кабельні споруди зв'язку; споруди радіорелейних ліній зв'язку; приймально-передавальні центри (радіомовлення і телебачення); системи стільникового, транкінгового, пейджингового радіозв'язку; земні станції супутникового зв'язку; станційні споруди дротових засобів зв'язку; станції дротового мовлення; автоматизовані системи управління та інформатизації; інформаційно-обчислювальні центри; локальні, регіональні, глобальні мережі; кінцеві телекомунікаційні термінали, інші матеріальні об'єкти телекомунікаційної інфраструктури.

Самостійну групу об'єктів становлять ресурси:

ресурс нумерації - сукупність або частину варіантів нумерації, які можливо використовувати в мережах зв'язку;

- нумерація - цифрове, літерне, символьне позначення або комбінації таких позначень, у тому числі коди, призначені для однозначного визначення (ідентифікації) мережі зв'язку та/або іiї вузлових або кінцевих елементів;

- радіочастотний спектр - сукупність радіочастот у встановлених Міжнародним союзом електрозв'язку межах, які можуть бути використані для функціонування радіоелектронних засобів або високочастотних пристроїв;

- орбітально-частотний ресурс [12].

Особливе місце займає спеціальний телекомунікаційний об'єкт, завдяки якому виникають правовідносини в телекомунікаційній сфері, - «трафік - навантаження, створюване потоком викликів, повідомлень і сигналів, які надходять на засоби зв'язку».

Наступним елементом правовідносин у сфері телекомунікації $є$ їх зміст.

Ця частина дослідження наукової роботи буде зосереджена на проблемах визначення системних ознак змісту суспільних відносин, які становлять предмет правового регулювання у телекомунікаційному праві.

Зміст правовідносин адміністративного характеру у сфері телекомунікацій складається iз прав й обов'язків їх учасників, що реалізують власну діяльність відповідно до норм права. Разом із тим важливо звертати увагу на суб'єкт правовідносин і специфічні риси об'єкта таких відносин. До загальних прав суб'єктів адміністративних правовідносин у межах сфери телекомунікацій відносяться право на:

- отримання достовірної та вчасної інформації;

- одержання послуг телекомунікаційного характеру; нікацій

- одержання інформації щодо змін, які стосуються тарифів на послуги у сфері телекому-

- відшкодування збитків, завданих через неправомірні дії осіб.

Суб'єктивні обов'язки полягають саме в забезпеченні телекомунікаційними послугами, процесі реєстрації й ліцензуванні діяльності в галузі зв'язку, а також задоволенні потреб споживачів телекомунікаційного характеру [10]. 
Правовідносини щодо телекомунікацій виникають у різних сферах діяльності. Розмежування телекомунікаційних та інших правовідносин - досить складне завдання. Його можна вирішити за функціональним змістом прав й обов'язків щодо об'єкта правовідносин.

Заради висвітлення окремих результатів дослідження щодо вивчення та розуміння системних ознак відносин суспільства в межах предмету регулювання телекомунікаційного права, потрібно визначити положення доктринального характеру щодо вивчення змісту відносин суспільства загалом та правовідносин зокрема, щодо формування теорії змісту відносин у суспільстві в межах сфери телекомунікаційного права й наукової формалізації предметності ієрархії множини відносин суспільства в телекомунікаційній сфері правового регулювання.

3 огляду на різноманітні методологічні й методичні підходи певних учених щодо розгляду категорії змісту відносин в суспільстві, які складають предмет правового регулювання як правової категорії, як базовий підхід задля дослідницьких завдань було прийнято підхід, який випливає 3 теорії складних (множинних) систем у праві (теорія гіперсистем) [14, 15].

Основним постулатом теорії систем у юридичній доктрині аксіологічно $\epsilon$ те, що правовідносини в будь-якому розумінні мають розглядатися як система, що має як мінімум три ключові складники - суб'єктів (мінімум - два), об'єкт (чи ієрархію об'єктів) та зміст правовідносин (взаємозв'язків між суб'єктами стосовно об'єкта). На даному етапі дослідження пропонується сконцентрувати увагу на змісті правовідносин.

Суспільне життя людей знаходить вияв у діяннях (діях чи бездіяльності). Періодичність дій (у взаємозв'язку) щодо певного предмета у просторі, часі та колі осіб дає визначення такому правовому феномену як діяльність. Однак за певних обставин правовідносини можуть і не виникати. Проте це не означає, що не існує суспільних відносин. Відсутність взаємозв’язків між учасниками у просторі та часі щодо певного предмету може свідчити тільки про їхній умовний, відносний характер, інакше кажучи - про відсутність предметної відносності.

До першого прояву ієрархії предметності суспільних відносин можна віднести їх будову. На рівні Конституції у межах законодавства було сформовано комплекс певних відносин у суспільстві. У межах визначених у Конституції правил поведінки між людьми, передусім, між громадянами нашої держави, регламентується певна система основних предметних відносин у суспільстві. Предметність цих відносин має нормативне визначення у двох площинах:

1) у вертикальній (влада - підпорядкування);

2) у горизонтальній (юридична рівність та незалежність сторін). Окремі з них знаходяться між цими площинами.

Наступна конкретизація правовідносин у межах конституційних норм визначається із потреб та інтересів спільних сфер діяльності людей у формі визначення правових норм на рівні юридичних законів. Так, наприклад, у розрізі охоплюваної теми дослідження слід звернутися до правових норм статті 92 Основного закону нашої держави, в якому поміж визначених предметних сфер відносин суспільства, які мають бути визначені лише законодавчими актами, $є$ норма про організацію та експлуатацію зв'язку.

Із цього випливає розуміння змісту конституційних правовідносин щодо такого їхнього предметного прояву як організація та експлуатація зв'язку. Разом із цим у Конституції України не розкривається сутність поняття «зв'язок». Законодавець логічно відносить визначення суспільних відносин у сфері зв'язку до спеціального нормативно-правового акту. Варто зазначити, що таким законом, який було прийнято майже за рік до прийняття Основного законодавчого акту України, був Закон України «Про зв'язок».

В ієрархії правовідносин у сфері зв'язку наступний рівень випливає із Закону України «Про поштовий зв'язок». У цьому законі законодавець визначив предметність відносин у суспільстві щодо поштового зв'язку у значенні приймання, обробки, перевезення й доставки (вручення) поштових відправлень, виконання доручень користувачів щодо поштових переказів, банківських операцій [2, ст. 1].

Провівши дослідження, було сформовано узагальнений погляд на визначення системних характерних рис та ознак змісту відносин суспільства в телекомунікаційному праві.

Основу змісту відносин суспільства в телекомунікаційному праві становлять пошук, поширення та отримання інформаційних даних дистанційно особою за допомогою будь-яких засобів.

Перший рівень змісту правовідносин сфери телекомунікацій можна визначити через множинність правових норм, які регулюють діяльність, пов'язану з підтриманням спілкування між особами, що знаходяться на великій відстані, враховуючи масове використання відповідних здобутків науково-технічного прогресу. 
Другий рівень розуміння змісту правовідносин (із погляду визначальної, спеціальної галузевої ознаки) - телекомунікаційні правовідносини - можна розглянути через категорію взаємопов'язаної множинності прав їхніх учасників, які зумовлюють для них обов'язки стосовно організації та експлуатації зв'язку різноманітними засобами чи способами спілкування на великій відстані в заданому масштабі, просторі та часі.

Останньою категорією для розгляду в межах даного дослідження стане категорія юридичних фактів. Особливості юридичних фактів - тобто дій або подій в телекомунікаційній сфері, що мають правові наслідки,. Такими науковці називають юридичні факти, в результаті настання яких у суб'єктів діяльності підприємницького чи господарського характеру завершується процес формування правоздатності в телекомунікаційній сфері, тобто, точніше кажучи, законне право експлуатувати телекомунікаційні об'єкти та надавати послуги.

Найбільш значимий для користувача в телекомунікаційній сфері юридичний факт - надання оператором зв'язку доступу для абонента. Юридичним фактом постає приєднання мережі електрозв'язку оператора до мережі електрозв'язку загального користування, яке варто розглядати у двох контекстах, як дію і як подію. Дію пов'язано з виконанням робіт оператора по приєднанню, тобто завершення технічного й технологічного циклів по виконанню фізичного стику телекомунікаційних мереж. Як подію, приєднання мережі електрозв'язку оператора до мережі електрозв'язку загального користування можна розглядати з метою визначення моменту для видачі уповноваженим державним органом дозволу на експлуатацію телекомунікаційного об'єкта.

Однак найбільш поширеним юридичним фактом $є$ саме допуск оператором абонента до телекомунікаційної мережі як дії, в результаті якої абонент отримує можливість реалізовувати свої права на прийом/передачу повідомлень по телекомунікаційних мережах [12].

Висновки. Специфіка змісту відносин у суспільстві, що складають предмет телекомунікаційного права, виходячи з концепції його розуміння через критерій підгалузі спеціальної частини комплексної галузі права (інформаційне право), визначається третім рівнем.

Контекст взаємозв'язку відносин у суспільстві, які складають предмет телекомунікаційного права, з іншими галузями права зумовлюється специфікою потреб іх учасників на рівні приватного права та окремими ознаками галузей публічного права [16]. Однак зв'язок адміністративно-телекомунікаційного права та інших основних галузей права буде розглянуто в наступному розділі наукової роботи.

Варто наголосити, що розгляд основних понять та категорій будь-якої галузі права досить кропіткий та потребує уваги дослідження, до якого входить процес вивчення великої кількості проблемних питань як-то предмет правового регулювання, його метод, принципи окремої галузі права, правові відносини, які виникають у відповідній сфері суспільного життя, суб'єктів, об'єкт, зміст цих правовідносин тощо.

\section{Список використаних джерел:}

1. Про інформацію : Закон від 02.10.1992 № 2657-ХІІ/Верховна Рада України. Відомості Верховної Ради Украӥни (ВВР). 1992. № 48, С. 650.

2. Про поштовий зв’язок : Закон від 04.10.2001 № 2759-III/Верховна Рада України. Відомості Верховної Ради України (ВВР). 2002. № 6, С. 39.

3. Про радіочастотний ресурс України : Закон від 01.06.2000 № 1770-III/Верховна Рада України. Відомості Верховної Ради України (ВВР). 2000. № 36, С. 298.

4. Про Національну комісію, що здійснює державне регулювання у сфері зв'язку та інформатизації : Указ, Положення від 23.11.2011 № 1067/2011/Президент України. Офіиійний вісник Президента України від 23.11.2011 р. № 31, С. 22. Стаття 1195.

5. Про затвердження Правил охорони ліній електрозв'язку : Постанова від 29.01.1996 № 135/КМУ. Режим доступу: http://zakon2.rada.gov.ua/laws/show/135-96-\%D0\%BF.

6. Про затвердження Правил надання та отримання телекомунікаційних послуг : Постанова, Правила від 11.04.2012 № 295/Кабінет Міністрів України. Офіиійний вісник України від 23.04.2012 p. № 29, С. 21. Стаття 1074. Код акту 61215/2012.

7. Про затвердження Правил взаємоз'єднання телекомунікаційних мереж загального користування : Рішення, Правила, Форма типового документа від 08.12.2005 № 155/НКРЗ. Офіційний вісник України від 15.02.2006 p. № 5, С. 223. Стаття 260. Код акту 35061/2006.

8. Тер-Степанян О.В. Сутність адміністративних правовідносин у сфері телекомунікацій. Право і Безпека. 2010. № 3. С. 119. 
9. Щербатюк Н.В. Сфера телекомунікацій як об’єкт адміністративно-правової охорони. Управління проєктами, системний аналіз і логістика. Технічна серія. 2012. Вип. 9. С. 425.

10. Тер-Степанян О.В. Сутність адміністративних правовідносин у сфері телекомунікацій. Право і Безпека. 2010. № 3. С. 120.

11. Алексеев С.С. Общая теория права : в 2 т. Т. 2. Москва : Юрид. лит., 1982. С. 138.

12. Телекоммуникационное право : учебное пособие. Екатеринбург. 2008. 56 с. Субъекты телекоммуникационных правоотношений. [Электронный ресурс]. Режим доступа: http://www.telecomlaw.ru/studyguides/UP TLKLaw 08.htm.

13. Про телекомунікації : Закон від 18.11.2003 № 1280-IV/Верховна Рада України. Відомості Верховної Ради України (ВВР). 2004. № 12. С. 155.

14. Лисенко С.А. Системний підхід у дослідженні інформаційної безпеки підприємств 3 точки зору теорії гіперсистем у праві. Європейські перспективи. 2016. С. 159-166.

15. Цимбалюк В.С. Інформаційне право (основи теорії і практики) : монографія. Київ : «Освіта України», 2010. С. 76-114.

16. Процишен М.В. Визначення системних ознак змісту суспільних відносин у телекомунікаційному праві. Науковий вісник публічного та приватного права. 2016. Вип. 6. Том 2. С. 10. 